DOI https://doi.org/10.30525/978-9934-588-92-1-62

\title{
ЗАГАЛЬНОПРАВОВІ ФУНКЦІї АДМІНІСТРАТИВНОГО ДОГОВОРУ
}

\author{
Кононець О. М. \\ кандидат юридичних наук, \\ дочент кафедри міжнародного, циивільного та комериійного права \\ Киівського національного торговельно-економічного університету \\ м. Київ, Украӥна
}

Реформування системи державного управління в Україні, поява нових форм і методів державного управління, розширення сфери використання адміністративного договору в політичній, економічній, соціальні сферах суспільних відносин, дозволяють виявити проблеми у сфері правової регламентації адміністративних відносин, визначити місце адміністративного договору в системі регулювання суспільних відносин, а також охарактеризувати його основні загальноправові функції.

Визначення і характеристика основних загальноправових функцій не можлива без окреслення самої категорії адміністративного договору, щодо тлумачення якого не має єдиної позиції вчених. В першу чергу звернемо увагу, що ст.4 Кодексу адміністративного судочинства України визначає адміністративний договір як спільний правовий акт суб'єктів владних повноважень або правовий акт за участю суб'єкта владних повноважень та іншої особи, що грунтується на їх волеузгодженні, має форму договору, угоди, протоколу, меморандуму тощо, визначає взаємні права та обов'язки його учасників у публічноправовій сфері і укладається на підставі закону [1].

Досліджуючи систему методів адміністративного і цивільного права крізь призму конвергенції диспозитивності та імперативності, О.Р.Радишевська відзначає, що прагнення України долучитися до європейської спільноти та європейських стандартів зумовлює поступове поширення застосування в адміністративному праві невластивого йому диспозитивного методу, який, зокрема, реалізується шляхом укладення адміністративних договорів в управлінських відносинах [2, с. 83].

Привертає увагу також думка Т.М. Тимчишина, який зазначає, що зміст адміністративного договору передбачає взаємні права та обов'язки учасників, що мають заданий, спрямований, заздалегідь визначений характер, який залежить від компетенційних повноважень 
тієї чи іншої сторони. За переконанням автора права та обов'язки органу виконавчої влади не повинні порушувати меж компетенції цього органу [3, с. 203].

3 огляду на тематику даного дослідження варто зупинитися на визначенні функцій та окресленні основних загальноправових функцій, які $\epsilon$ притаманними саме адміністративному договору. Так, Л.В. Шкварок розуміє під функціями правові категорії, які відображають елементи змістовної характеристики цивільно-правового договору та характеризують його в цілому і тому мають істотне значення для пізнання явищ, що охоплені предметом певного договору [4, с. 125].

Акумулювавши думки провідних вчених щодо визначення поняття функцій права Р.В. Зварич та Б.Л. Гривнак висновують, що це $\epsilon$ соціальне призначення права та напрями його правового впливу. Поряд 3 цим автори визначають, що систему функцій права складає комплексна структура, яка поділяється на декілька рівнів та реалізується через систему права, зокрема через галузі, інститути, норми, договори, прецеденти, акти застосування права тощо [5, с. 27].

Як правило в теорії права функції поділяють на міжгалузеві, загальноправові, галузеві, а також функції окремих інститутів та норм права. Усе окреслене вище дає можливість визначити основні загальноправові функції, які $є$ притаманними адміністративному договору:

1) регулятивна, яка полягає у тому, що в результаті укладення адміністративного договору встановлюються певні правила поведінки для його сторін; адміністративний договір виступає регулятором суспільних відносин, координує взаємозв'язки між його суб'єктами. Зазначена функція є одним з важливих напрямків правового впливу на суспільні відносини, який полягає у встановленні суб'єктивних прав та юридичних обов'язків, визначенні кола суб'єктів відповідних правовідносин та обставин, які сприяють виникненню, зміні або припиненню цих відносин.

2) комунікативна функція - адміністративний договір являє собою угоду, компроміс між суб'єктами адміністративного права, що сприяє взаємодії та взаємозв'язку між ними;

Нажаль, на даний час дуже мало уваги українських вчених приділялося зазначеній функції. В той же час, підтвердження власної позиції знаходимо у дослідженні О.Л.Чорнобая, який зазначає, що право, як практично система дії, засноване на взаєморозумінні, без якого саме його існування неможливе. Автор висновує, що нема права без інформації, структурованої джерелом права і адресованої суб'єктам правової комунікації. Але умовою правової комунікації є не стільки 254 
зміст інформації. I навіть не стільки ії прескриптивна (нормативна) форма, скільки переконуюча сила, без якої неможлива сама правова комунікація як практична взаємодія [6, с. 499].

3) інформаційна - в результаті укладення адміністративного договору відбувається фіксація волі та волевиявлення сторін, які досягли згоди щодо умов адміністративного договору;

4) охоронна функція здійснюється шляхом встановлення санкцій, передбачених як імперативно (в законодавстві), так і диспозитивно (за згодою сторін адміністративного договору), за порушення умов договору, а також встановлення гарантій, спрямованих на ефективне виконання умов адміністративного договору;

5) розподільча або дистрибутивна функція полягає у розподілі прав та обов'язків між суб'єктами адміністративного права, які кореспондують між собою, на основі яких виникають адміністративноправові відносини;

6) виховна функція. Процес укладення адміністративного договору сприяє активізації правової активності суб'єктів адміністративного права, їх правомірній поведінці, виховує самостійність мислення, спонукає вивчати та аналізувати адміністративно-правові норми, усвідомлювати та відстоювати публічні інтереси.

Перелік загальноправових функцій адміністративного договору, який визначено вище не є вичерпним. Аналіз наукових джерел доводить, що даному питанню не приділялося належної уваги. То ж, це означає, що $є$ необхідність проведення комплексних наукових досліджень у цьому напрямку. Також варто відмітити, що усі зазначені загальноправові функції адміністративного договору є взаємопов'язаними та взаємообумовленими.

Підводячи підсумки варто звернути увагу, що трансформації, які відбуваються у сфері державного управління, дають можливість нового осмислення адміністративного договору як унікального засобу управління суспільними відносинами, здатного врегульовувати зазначені відносини, реалізуючи низку загальноправових, галузевих та інших функцій. Адміністративний договір може розглядатися як джерело права у конкретних взаємовідносинах. Відтак, є необхідність доктринального вивчення не лише понятійного апарату, а сутнісних характеристик функцій, ознак та інших елементів, які допоможуть краще зрозуміти правову природу адміністративного договору. 


\title{
Література:
}

1. Кодекс адміністративного судочинства України: Закон України від 06.07.2005 p. № 2747-IV / Верховна Рада України. URL: https://zakon.rada.gov.ua/laws/show/2747-15\#Text.

2. Радишевська О.Р. Адміністративне та цивільне право в умовах євроінтеграції: на стику доктрин. Правова держава. 2020. № 37. С. 80-89.

3. Тимчишин Т.М. Адміністративно-правовий договір як акт правового застосування. Загальна характеристика. Науковий вісник Львівського державного університету внутрішніх справ. 2018. № 2. C. 199-207.

4. Шкварок Л.В. Функції договору в приватному праві. Філософські та методологічні проблеми права. 2011. № 1. С. 124-134.

5. Зварич Р.В., Гривнак Б.Л. Регулятивна функція права у системі функцій права. Науково-інформаційний вісник Івано-Франківського університету права імені Короля Данила Галицького. Серія: Право. 2017. № 4(16). С. 20-28.

6. Чорнобай О.Л. Комунікативна функція права: інформаційноінформаційний вимір. Науковий вісник Львівського державного університету внутрішніх справ. 2013. № 1. С. 496-507.

DOI https://doi.org/10.30525/978-9934-588-92-1-63

\section{ПУБЛІЧНЕ АДМІНІСТРУВАННЯ ЯК ЗАСІБ ЗАХИСТУ ПРАВ, СВОБОД ТА ІНТЕРЕСІВ ГРОМАДЯН}

\author{
Косміна I. A. \\ викладач вищої категорії відділення «Правознавство» \\ Харківського державного автомобільно-дорожнього коледжу \\ Гончаренко Н. М. \\ викладач вищої категорії відділення «Правознавство» \\ Харківського державного автомобільно-дорожнього коледжу \\ м. Харків, Україна
}

Сучасний стан української державі є дуже складним. Він перебуває на такому етапі розвитку, що змушує переосмислювати і змістовно розвивати цілу низку усталених понять, що максимально впливає на 